Alaska Division of Geological \& Geophysical Surveys

MISCELLANEOUS PUBLICATION 151

\title{
SECOND ANNUAL ALASKA STRATEGIC AND CRITICAL MINERALS SUMMIT
}

November 30, 2012, Princess Hotel, Fairbanks, Alaska

Contributions by:

J.N. Adleman and E. Bluemink

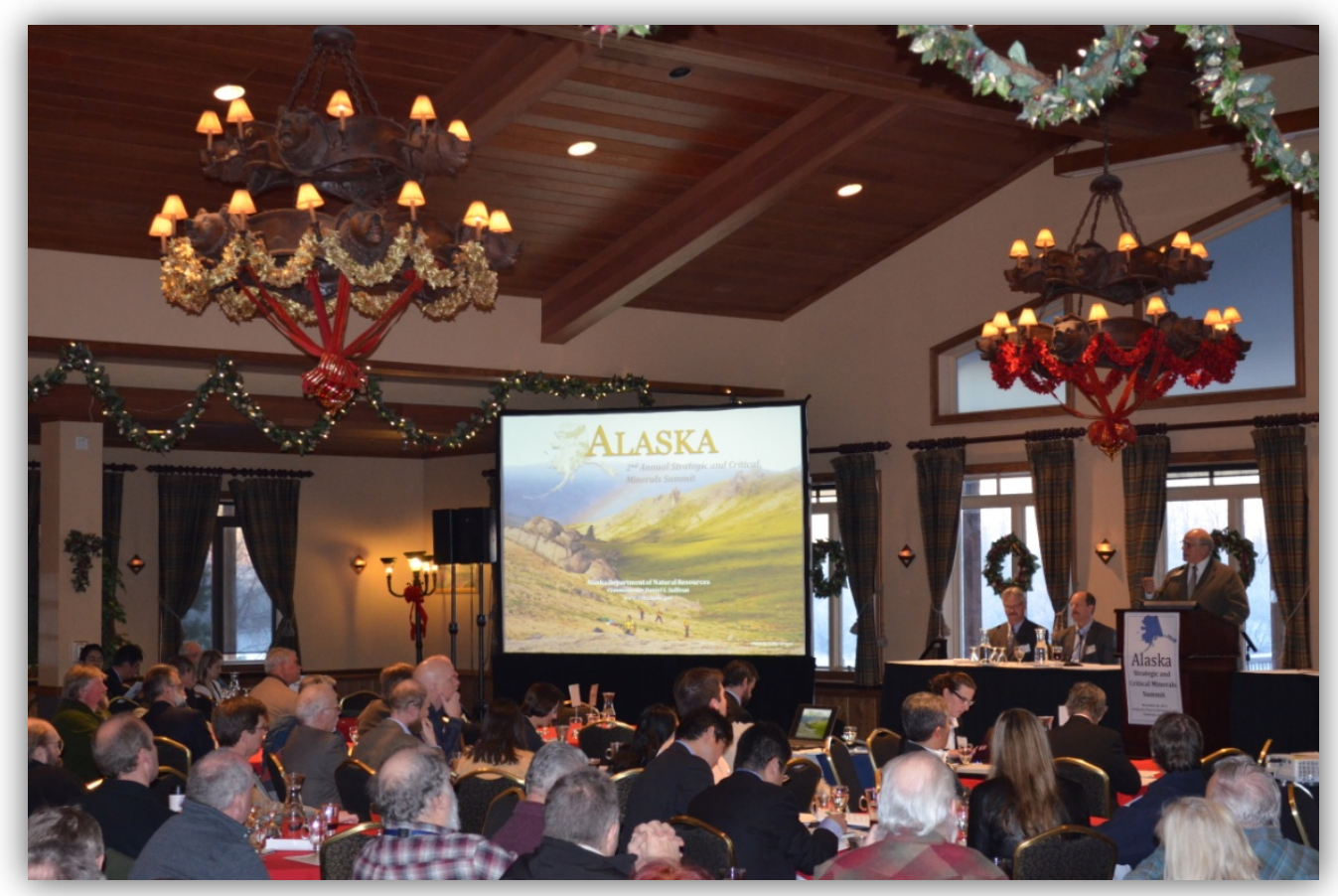

Released in May 2013

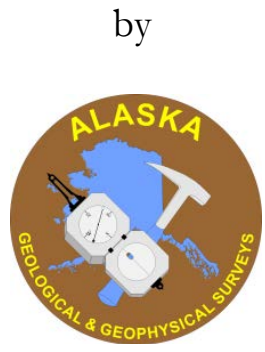

STATE OF ALASKA

DEPARTMENT OF NATURAL RESOURCES

Division of Geological \& Geophysical Surveys

3354 College Road

Fairbanks, Alaska 99709-3707

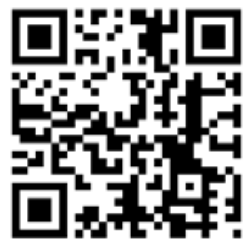




\section{TABLE OF CONTENTS}

\section{INTRODUCTION}

Update on State of Alaska Strategic Minerals Initiative

Commissioner Dan Sullivan, Alaska Department of Natural Resources

\section{WELCOME AND MORNING ADDRESS}

The Honorable U.S. Senator Lisa Murkowski

Ranking Member, U.S. Senate Committee on Energy and Natural Resources

\section{INVESTIGATING ALASKA'S STRATEGIC MINERAL POTENTIAL}

Alaska Strategic and Critical Minerals Potential and Assessment

Director Bob Swenson, Alaska Division of Geological \& Geophysical Surveys, State Geologist

USGS Minerals Resources Program and Alaska Strategic Resources

Larry Meinert, Program Coordinator, Minerals Research Program, U.S. Geological Survey

Strategic and Critical Metals in Alaska: A Mining Industry Perspective

Curtis Freeman, President, Avalon Development Corporation

\section{ACCESS TO ALASKA'S LANDS AND RESOURCES}

The Honorable Alaska Senator John Coghill

Alaska Senate Majority Leader

Deputy Commissioner Ed Fogels, Alaska Department of Natural Resources

Ethan Schutt, Senior Vice President of Land and Energy, Cook Inlet Region Incorporated (CIRI)

Mining Potential and Mineral Access in the Bering Strait Region

Matt Ganley, Vice President of Resources and External Affairs, Bering Straits Native Corporation (BSNC)

Strategic Mineral Development is Critical for Sustainable Economies

Lance Miller, Vice President of Natural Resources, $N A N A$ Regional Corporation

\section{KEYNOTE}

The Coming Global Resource Scarcity: American and Alaska's Role

Michael Silver, President and Chairman of the Board, American Elements

\section{STRATEGIC MINERALS - NATIONAL POLICY AND GLOBAL SECURITY}

Dan McGroarty, President, American Resources Policy Network

JOGMEC's Role in Securing the Supply of Critical Minerals

Hiroyuki Katayama, Assistant General Manager, Japan Oil, Gas and Metals Corporation (JOGMEC) 


\section{PROJECT RESEARCH, DEVELOPMENT, AND FINANCING}

Commissioner Susan Bell, Alaska Department of Commerce, Community, and Economic Development

Mineral and Mining Research at UAF

Mark Myers, University of Alaska Fairbanks (UAF) Vice Chancellor for Research

Bokan Mountain Heavy Rare Earths

Ken Collison, Chief Operating Officer, Ucore Rare Metals

Investing in Alaskans

Mark Davis, Deputy Director for Infrastructure Development, Alaska Industrial Development and Export Authority (AIDEA)

\section{REGULATORY AND STAKEHOLDER ISSUES}

Mary Sattler, Manager of Community Development and Sustainability, Donlin Gold

Large Mine Permitting in Alaska

Director Tom Crafford, Alaska Department of Natural Resources, Office of Project Management and Permitting

Karl Hanneman, Alaska General Manager, Tower Hill Mines Inc., Livengood Project

Lorna Shaw, Chairwoman, Greater Fairbanks Chamber of Commerce

\section{CLOSING REMARKS}

The Honorable Mead Treadwell, Alaska Lieutenant Governor

\section{APPENDIX}

I. AGENDA

II. ACRONYMS 


\section{PROCEEDINGS \\ SECOND ANNUAL ALASKA STRATEGIC AND CRITICAL MINERALS SUMMIT}

November 30, 2012, Princess Hotel, Fairbanks, Alaska

Summary compiled by:

J.N. Adleman ${ }^{1}$ and E. Bluemink ${ }^{2}$

\section{INTRODUCTION}

The State of Alaska and University of Alaska Fairbanks convened the Second Annual Strategic and Critical Minerals Summit in Fairbanks on November 30, 2012, with participation from federal, state, and international governments, mining companies, manufacturers, Alaska Native corporations, and potential investors. Roughly 210 individuals attended the all-day event.

The purpose of the summit was to present new information and stimulate discussion regarding the challenges and opportunities facing strategic and critical minerals development in the U.S. and Alaska, and to promote investment in developing Alaska's strategic and critical mineral resources. The following is a summary of the presentations.

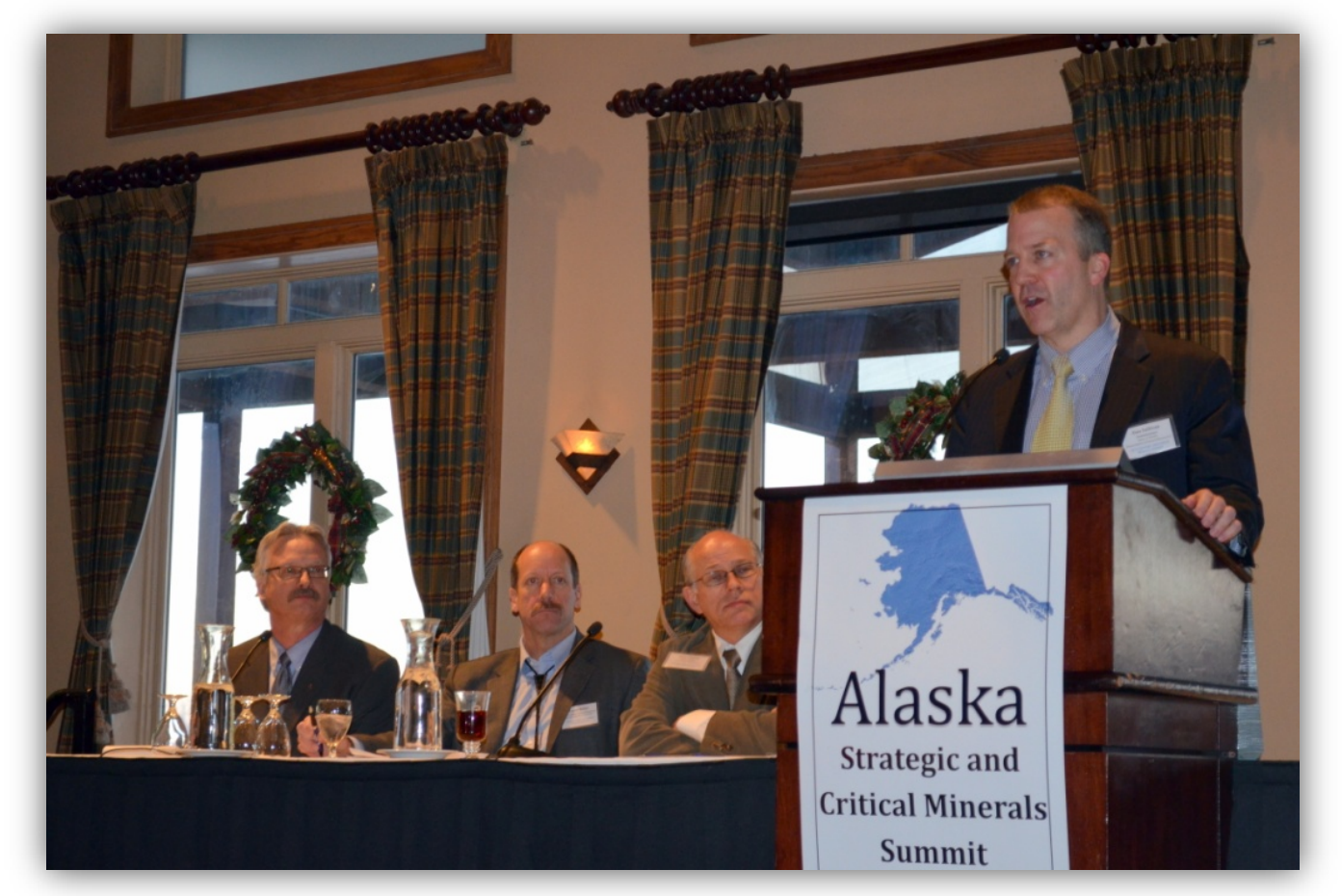

\footnotetext{
1 Department of Commerce, Community, and Economic Development, Division of Economic Development, 550 West 7th Avenue, Suite 1770, Anchorage, Alaska 99501-3569; jennifer.adleman@alaska.gov

2 Department of Natural Resources, Office of the Commissioner, 550 West 7th Avenue, Suite 1400, Anchorage, Alaska 99501-3561; elizabeth.bluemink@alaska.gov
} 


\section{WELCOME AND MORNING ADDRESS}

Alaska Department of Natural Resources (DNR) Commissioner Dan Sullivan provided an overview of current, ongoing, and future State of Alaska activities, including mineral assessments, ongoing research regarding techniques for processing rare-earth minerals and efforts to improve the state's permitting process. He reported significant progress on these activities since the State convened the inaugural Strategic and Critical Minerals Summit in Fairbanks in September 2011. At that event, Alaska Governor Sean Parnell announced a five-part strategy to spur the exploration of rare-earth elements and other strategic minerals in Alaska, with the ultimate goal of mining and processing them in Alaska. Later that year, the Alaska Legislature appropriated $\$ 2.73$ million for the Division of Geological \& Geophysical Surveys’ Rare-Earth Elements and Strategic Minerals Assessment, supported research and development collaborations through the University of Alaska, and enacted some reforms to modernize the State's permitting process.

The Honorable U.S. Senator Lisa Murkowski discussed the nation's continuing dependency on foreign supplies of strategic and critical minerals and how China's control of this supply has heightened the need for resource development in the United States and the passage of legislation to safeguard future supplies and availability of these resources. She said the nation and the state should focus their efforts on the most feasible projects with the highest benefit, and those most likely to come to fruition. Projects with identifiable, logistically supportable, and cost-efficient ore, alongside transportation, energy, and export infrastructure should be championed. Her remarks were delivered in a recorded video from Washington, D.C.

\section{INVESTIGATING ALASKA’S STRATEGIC MINERAL POTENTIAL}

The early morning presentations focused on recent geologic investigations of Alaska's strategic mineral potential.

Alaska Division of Geological \& Geophysical Surveys (DGGS) Director Bob Swenson discussed the division's work on the Rare-Earth Elements and Strategic Minerals Assessment funded by the Alaska Legislature. This project includes statewide geologic fieldwork and the compilation and reanalysis of historic geochemical data using current techniques. Swenson provided an overview of recent geochemical and geophysical survey data collected by the division. This summary included results from airborne geophysical studies in the Farewell area, and Donlin epithermal areas, 2010 airborne geophysical and 2011 geologic mapping results in the Moran area, and a comprehensive assessment of the Ray Mountains. He summarized the division's wide array of mineral datasets and studies that are available to the public and potential investors via the DGGS website, and the division's efforts to make historical databases and reports available online, as well.

Swenson also introduced the new publication, Fossil Fuel and Geothermal Energy Sources for Local Use in Alaska (Special Report 66), which provides a science-based summary of potential energy resources in rural Alaska that could be tapped to bring down energy costs for rural residents who rely on expensive imports. Such energy resources could also be used to power rural development projects, such as mines.

U.S. Geological Survey (USGS) Minerals Research Program Coordinator Larry Meinert discussed how his agency is responding to the growing demand and limited supply of strategic and critical minerals, including rare-earth elements. Meinert also described his agency's ongoing mineral 
evaluation, which includes the identification and assessment of strategic and critical mineral-bearing ore bodies, through the increased and expanded use of traditional and advanced field methodologies, geochemical and geophysical analyses, and an understanding of gross regional tectonics and geologic regimes conducive to these deposits. Nationwide efforts include studying critical metals in black shales, rare-earth potential in the southeastern United States, and unconventional resources in high sulfidation systems typically known for gold potential. In Alaska, for the federal fiscal year 2013, the USGS is focused on projects at Bokan Mountain on Prince of Wales Island, studies on the tectonic framework of Arctic Alaska, and reconciliation of the YukonTanana terrane.

Avalon Development Corporation President Curt Freeman gave an overview of the companies currently exploring for strategic and critical minerals in Alaska. These companies include Ucore Rare Metals at the Bokan Mountain and Ray Mountains projects, Contango ORE at Salmon Bay and Stone Rock Bay, Pure Nickel at MAN and Salt Chuck, Pacific North West at Tonsina, and Graphite One at Graphite Creek. Freeman also described challenges to development in Alaska-including the fact that many prospective areas are currently closed to mineral entry-and around the world. Freeman explained that specialty metals, while critical for our modern society, are utilized in very small quantities. Therefore, total worldwide production of any given rare metal is small in comparison to metals like iron, copper, and zinc. Alaska explorers and developers of these metals need to plan for the wide and often rapid price variations in the rare metals market, and the detrimental effects these price variations have on mine profitability, he said.

Update on State of Alaska Strategic Minerals Initiative http://www.dggs.alaska.gov/webpubs/dggs/mp/oversized/mp151 Dan Sullivan.pdf Commissioner Dan Sullivan, Alaska Department of Natural Resources

The Honorable U.S. Senator Lisa Murkonski

http://www.dggs.alaska.gov/webpubs/dggs/mp/oversized/mp151_Lisa Murkowski.mp4 Ranking Member, U.S. Senate Committee on Energy and Natural Resources

Alaska Strategic and Critical Minerals Potential and Assessment http://www.dggs.alaska.gov/webpubs/dggs/mp/oversized/mp151 Bob_Swenson.pdf State Geologist and Director Bob Swenson, Alaska Division of Geological \& Geophysical Surveys

USGS Minerals Resources Program and Alaska Strategic Resources http://www.dggs.alaska.gov/webpubs/dggs/mp/oversized/mp151 Larry Meinert.mov Larry Meinert, Program Coordinator, Minerals Research Program, U.S. Geological Survey

Strategic and Critical Metals in Alaska: A Mining Industry Perspective http://www.dggs.alaska.gov/webpubs/dggs/mp/oversized/mp151 Curt Freeman.pdf Curtis Freeman, President, Avalon Development Corporation

\section{Referenced during presentation:}

Fossil Fuel and Geothermal Energy Sources for Local Use in Alaska (Special Report 66) http://www.dggs.alaska.gov/pubs/id/24264 


\section{ACCESS TO ALASKA'S LANDS AND RESOURCES}

The summit's late morning sessions focused on opportunities on state and private lands for natural resource development.

The presenters described challenges facing mineral development in Alaska, such as remote arctic conditions and the lack of infrastructure, transportation, and energy supplies, as well as the high cost of energy. In his introduction of the speakers, the Honorable Alaska Senator and Senate Majority Leader John Coghill stated that partnerships, dialogue, and additional work are needed to overcome these challenges.

DNR Deputy Commissioner Ed Fogels provided an overview of land ownership in Alaska. Encompassing more than 586,412 square miles, Alaska is larger than all but 18 sovereign nations. Sixty percent of Alaska's land mass is under federal ownership, 27 percent falls under state ownership, and 12 percent is owned by Alaska Native Claims Settlement Act (ANCSA) regional Native corporations. Though land ownership has been established for most lands in Alaska, the federal conveyance of roughly 5.3 million acres to the State of Alaska and about 1.9 million acres to regional Native corporations is still pending, and this includes mineral-rich lands. The state government and ANCSA regional Native corporations are working with the U.S. Bureau of Land Management to complete these land selections.

Fogels described the efforts of the Alaska Statewide Digital Mapping Initiative to generate highresolution digital base maps for Alaska. This includes acquiring statewide, high-resolution SPOT satellite images, and developing a new digital elevation model using IfSAR technology over the entire state. Fogels also discussed the State of Alaska's Roads to Resources Program, which is studying new transportation routes in the Ambler mining district, the Tanana area, and other locations that are prospective for minerals, timber, hydrocarbons, and agriculture.

Fogels discussed DNR's ongoing work with other state agencies to improve the permitting process. With financial support and backing from Governor Parnell and the Legislature, DNR has been able to increase its staff size, decrease a backlog of permit applications, and make significant progress to modernize the state permitting process using new technology and automation. Statutory changes include the passage of House Bill 361 (Disposals of State Resources/Royalties), which made revisions to statutes governing leasing and disposal programs. The changes are expected to reduce the permitting burden on the applicant and free more time for staff to work on processing applications. Additional statutory and regulatory reforms are expected as part of the ongoing permitting modernization effort.

Cook Inlet Region, Incorporated (CIRI) Senior Vice President of Land and Energy Ethan Schutt gave an overview of Alaska's Native corporations and provided recommendations on how to conduct business with them. CIRI is the regional corporation for the Cook Inlet locale. As the area's largest private landowner, CIRI is a diversified investor and developer of several large-scale infrastructure projects, including Tikahtnu Commons, a regional retail and entertainment center, and Fire Island Wind LLC, a producer of sustainable wind energy for Southcentral Alaska. CIRI also holds several mineral assets, including some classified as rare-earth-element-bearing mineral prospects.

Schutt explained that ANCSA, passed by Congress (1971 Codified at 43 U.S.C. 1601 et seq.), created 12 regional corporations and more than 200 village corporations, capitalizing them with 
approximately $\$ 1$ billion and about 40 million acres. The regional corporations generally own the mineral estate while surface estate can have village or regional corporation ownership. The village corporation usually holds the surface estate for the lands nearby.

Schutt emphasized the need for developers interested in a particular region of the state to learn about its cultural and general history and its land ownership patterns. Developers should allot plenty of time to identify the area's land use and exploration rights, its planning and decision-making processes, and what access is available and/or disputed, he said. Schutt encouraged firms interested in partnering with ANCSA corporations to incorporate local hire and leadership from nearby communities, and to recognize that Alaska Native corporations must balance monetary and nonmonetary objectives.

NANA Regional Corporation Vice President of Natural Resources Lance Miller discussed a proposed transportation corridor in the Ambler region to extend access to mineralized areas as well to Northwest Arctic village communities, and to link existing infrastructure to tidewater and rail. NANA, the regional Alaska Native corporation for Northwest Alaska, has an exploration agreement with NovaCopper on the Upper Kobuk Mineral Project, predominantly copper mine prospects in the Ambler mining district. With any development of a road, area communities are interested in reducing the high cost of energy while restricting access to subsistence resources.

NANA obtains a significant portion of revenue from mineral resources on its land-primarily from the Red Dog zinc and lead mine. Operated by Teck Limited, the Red Dog mine is the largest zinclead mine in the world; it continues to provide significant employment and revenue to NANA shareholders. Since the mine began production, NANA has distributed $\$ 512$ million statewide to the Alaska Native regional and village corporations under the 7(i) and 7(j) provisions of ANCSA. The 7 (i) provision requires regional corporations to share 70 percent of their resource revenues among the remaining regional corporations. Additionally, under Section 7(j), half of the money each regional corporation receives is shared with its region's village corporations.

Bering Straits Native Corporation (BSNC) Vice President of Resources and External Affairs Matt Ganley provided an overview of the Seward Peninsula, where his Nome-based regional corporation is the dominant private landowner. Communities in the Seward Peninsula region have an extensive gold mining history, and a number of companies are continuing to explore for minerals in the region. The region's mineral potential extends beyond gold to include silver, tin, uranium, thorium, beryllium, molybdenum, and rare-earth elements, according to Ganley.

BSNC has worked with Millrock Resources Inc. on the Council and Bluff gold exploration projects east of Nome, Ganley said. In late 2012, BSNC acquired the Alaska Gold Company, a subsidiary of NOVAGOLD Resources Inc., which holds a large mineral estate including the Rock Creek and Big Hurrah gold deposits near Nome. At the time of Ganley's presentation, BSNC was considering how best to develop these assets, known collectively as the Nanuuq Gold Project.

Deputy Commissioner Ed Fogels, Alaska Department of Natural Resources

http://www.dggs.alaska.gov/webpubs/dggs/mp/oversized/mp151 Ed Fogels.pdf

Ethan Schutt, Senior Vic President of Land and Energy, Cook Inlet Regional Incorporated (CIRI) http://www.dggs.alaska.gov/webpubs/dggs/mp/oversized/mp151_Ethan Schutt.pdf 
Mining Potential and Mineral Access in the Bering Strait Region

http://www.dggs.alaska.gov/webpubs/dggs/mp/oversized/mp151_Matt Ganley.pdf

Matt Ganley, Vice President of Resources and External Affairs, Bering Straits Native Corporation (BSNC)

Strategic Mineral Development is Critical for Sustainable Economies

http://www.dggs.alaska.gov/webpubs/dggs/mp/oversized/mp151_Lance Miller.pdf

Lance Miller, Vice President of Natural Resources, NANA Regional Corporation

\section{KEYNOTE}

\section{THE COMING GLOBAL RESOURCE SCARCITY: AMERICAN \& ALASKA'S ROLE}

Michael Silver, President and Chairman of the Board, American Elements

American Elements Chairman and Chief Executive Officer Michael Silver delivered the summit's lunch hour keynote speech. American Elements is a privately-owned company supplying rare-earth elements and other strategic minerals to the U.S. military, federal laboratories, and many private customers.

Silver gave his outlook on strategic and critical mineral demand and development and related issues of global security. Despite the large number of rare-earth prospects worldwide, the lion's share of proven reserves are contained in only one country-China. The production of many other equally critical minerals, such as niobium, lithium, and tungsten, is further constrained to single countries including Brazil, Bolivia, and China. Silver observed that this tenuous global disproportion was not well understood or appreciated until the dispute in 2010 between Japan and China over the Senkaku Islands, when China cut off Japan's rare-earth supply.

Silver said China charges a higher price for exports of rare-earth elements than it does domestically, and international buyers pay as much as one-third more than Chinese buyers. This is one reason why General Electric, in 2003, opened its China Technology Center in Shanghai, ${ }^{3}$ he said. Technology transfer from foreign companies to state-owned companies can be a requirement of doing business in China, according to Silver. Additionally, China is capitalizing on new rare-earth prospects in Germany and Greenland and is discussing trade alliances with Danish authorities to mine deposits in Greenland. Silver also predicted high-seas disputes over rare earths, particularly the South China Sea.

Silver said the United States should enter the global market for rare earths as China has done in the developing world. While the U.S. focuses on providing financial aid to developing nations, China has provided billions of dollars in direct infrastructure development in exchange for access to resources, he said. In Afghanistan, the Chinese are conducting exploration after the United States secured access and assessed the nation's mineral potential. America needs to follow China's lead, he said.

While some are seeking to address supply constraints on rare-earth elements by identifying potential substitute materials - notably for use in lighting fixtures and electric car motors- this is not how China sees or is planning for the future, according to Silver. It's disputable whether any future rare-

\footnotetext{
${ }^{3}$ The GE China Technology Center (CTC) opened in 2000 in the Shanghai Caoheijing Development Zone, and was relocated to its current home in the Zhangizang High-Tech Park in May 2003, according to the General Electric company website.
} 
earth replacements can maintain or improve energy efficiency, or be available with no increase in cost. In addition, Silver contended that federal reporting requirements for minerals set out in Section 1502 of the Dodd Frank Wall Street Reform and Consumer Protection Act (2010) will constrain the development of green technology ${ }^{4}$.

Silver discussed the portrayal of miners in the popular media and by the environmental movement. Hollywood tends to portray resource extraction in a negative light while promoting alternative energy development. Both Hollywood and some environmentalists are failing to recognize that alternative energy development relies on the mining of strategic and critical minerals. In reality, Silver said, the aspirations of environmentalists and miners are not all that different from one another.

The Coming Global Resource Scarcity: American \& Alaska's Role http://www.dggs.alaska.gov/webpubs/dggs/mp/oversized/mp151_Michael Silver.pdf Michael Silver, President and Chairman of the Board, American Elements

\section{Referenced during presentation}

'Call of Duty' video game highlights real threat http://www.washingtontimes.com/news/2012/nov/22/call-of-duty-video-game-highlights-realthreat/

U.S. minerals supplies threatened by China

The Washington Times

Thursday November 22, 2012

Hitachi spins up 'leccy fan motor sans rare earths http://www.theregister.co.uk/2012/04/13/rare earth hitachi motor

Where's your monopoly now, China?

The Register

April 13, 2012

A push to make motors with fewer rare earths

http://www.nytimes.com/2012/04/22/automobiles/a-push-to-make-motors-with-fewer-rareearths.html?pagewanted $=$ all $\& \quad \mathrm{r}=2 \&$

The New York Times

April 20, 2012

China sees Greenland as potential rare earth competitor

http://www.bullionstreet.com/news/china-sees-greenland-as-potential-rare-earth-competitor/2101 BullionStreet

June 18, 2012

\footnotetext{
${ }^{4}$ Section 1502 requires persons to disclose annually whether any conflict minerals that are necessary to the functionality or production of a product of the person, as defined in the provision, originated in the Democratic Republic of the Congo or an adjoining country and, if so, to provide a report describing, among other matters, the measures taken to exercise due diligence on the source and chain of custody of those minerals, which must include an independent private sector audit of the report that is certified by the person filing the report. Certain aspects of this rule will require consultation with other federal agencies, including the State Department, the Government Accountability Office, and the Commerce Department. Persons are not required to comply with these rules until the first full fiscal year after the date on which the Commission issues its final rules. SEC website (http:/ / www.sec.gov/spotlight/dodd-frank/speccorpdisclosure.shtml)
} 
China makes $\$ 15 \mathrm{~b}$ direct investment in Africa

http://www.ghanabusinessnews.com/2012/11/09/china-makes-15b-direct-investment-in-africa-

statement/

GBN Ghana Business News

November 9, 2012

BMO Capital Markets named world's best metals and mining investment bank http://www.bmocm.com/aboutus/news/detail/?id=22843

BMO Capital Markets

March 24, 2011

5 endangered elements that America needs

http://www.huffingtonpost.com/michael-silver/endangered-elements b 2211745.html

The Huffington Post

November 29, 2012

\section{STRATEGIC MINERALS - NATIONAL POLICY AND GLOBAL SECURITY}

Two speakers with expertise in minerals policy and global resource development gave presentations during the summit's early afternoon session. Their presentations focused on national policy and global security as they pertain to the development of strategic minerals.

In his presentation, American Resources Policy Network (ARPN) President Dan McGroarty critiqued existing federal policy relating to strategic minerals. ARPN is a Washington, D.C.-based non-profit organization that promotes public awareness of U.S. dependency on foreign sources for its mineral needs and the dangers created by this dependency. McGroarty stated that other industrialized countries — such as Australia and Canada — are moving much faster than the United States to extract and process locally hosted rare-earth-bearing minerals and explore the globe to secure additional, foreign sources of these raw materials.

McGroarty summarized federal activities and legislation related to strategic mineral development, including S. 1113: Critical Minerals Policy Act of 2011, H.R. 2011: National Strategic and Critical Minerals Policy Act of 2011, and H.R.4402: Strategic and Critical Minerals Production Act. These bills had seen little action in Congress. Meanwhile, the Obama Administration was fighting China's trade practices and price fixing regarding strategic mineral supplies through the World Trade Organization's (WTO) dispute resolution process. McGroarty said that resolving the trade dispute was unlikely to address growing demand for such minerals. To address the latter, the United States would need to undertake long-term planning such as that conducted by other producing nations such as China.

Relative to Alaska, ARPN issued a report titled Reviewing Risk: Critical Metals and National Security, which includes a "Risk Pyramid", a visual perspective on the relative ranking of 46 metals and minerals identified by ARPN_using U.S. government studies_as critical and strategic. According to the report, 39 of these 46 minerals are found in Alaska. Alaska's participation in shaping Washington, D.C., policy regarding strategic minerals is a matter of economic competitiveness, technological developments, and national security, McGroarty said. 
In his presentation, Hiroyuki Katayama, assistant general manager for the Vancouver office of the Japan Oil, Gas and Metals Corporation (JOGMEC), discussed his country's reliance on imported oil, natural gas, non-ferrous metals, and minerals such as rare-earth elements. Japan's urgent need to secure stable and diverse supplies of strategic and critical minerals led to the development of the Strategy for Ensuring Stable Supplies of Rare Metals, a guidance document published in 2009 by Japan's Ministry of Economy, Trade and Industry (METI). JOGMEC is one of the government entities responsible for implementing the four strategic principles laid out in this document securing overseas sources, developing recycling technologies and alternatives, and stockpiling these resources. JOGMEC is able to take early-stage risk to finance overseas exploration as a joint-venture partner or by transferring those contractual interests to Japanese companies. JOGMEC is also able to provide financial support directly to Japanese companies conducting overseas exploration. A case in point is JOGMEC's loan support to ITOCHU Corporation of Japan to support work at Pure Nickel Inc.'s MAN project.

Katayama raised concerns that the lengthy and unpredictable federal permitting process may impact the ability of a U.S. mining project to move with the market, which is changing rapidly, particularly in the case of strategic and critical minerals. Both he and McGroarty raised concerns about the possibility that the U.S. Environmental Protection Agency (EPA) will use its veto power over largescale mine permitting in Alaska's Bristol Bay region. The perception is growing that a company may have to fight just to initiate the permitting process, chilling the investment climate for any project. Other existing challenges to mining in Alaska include limited access to transportation, energy and port infrastructure, which increases a project's capital costs.

Katayama also discussed some of Alaska's advantages. He described Alaska as a mining-friendly jurisdiction with a skilled, educated and well-trained workforce. Unlike some Canadian provinces, Alaska's Native land ownership is well-established and the state's geographic location provides the shortest global transportation routes to Japan. These advantages, combined with Alaska's significant mineral potential, make the state an attractive mining jurisdiction for Japanese investment, he said.

Dan McGroarty, President, American Resources Policy Network.

http://www.dggs.alaska.gov/webpubs/dggs/mp/oversized/mp151 Dan McGroarty.mov

JOGMEC's Role in Securing the Supply of Critical Minerals

http://www.dggs.alaska.gov/webpubs/dggs/mp/oversized/mp151_Hiroyuki_Katayama.pdf

Hiroyuki Katayama, Assistant General Manager, Japan Oil, Gas and Metals Corporation (JOGMEC)

\section{Referenced during presentation}

ARPN Reviewing Risk: Critical Metals and National Security http://americanresources.org/reports-analysis/american-resources-critical-metals-report/

ARPN Risk Pyramid

http://americanresources.org/reports-analysis/risk-pyramid/

METI Strategy for Ensuring Stable Supplies of Rare Metals http://www.meti.go.jp/english/press/data/20090728 01.html 


\section{PROJECT RESEARCH, DEVELOPMENT, AND FINANCING}

The summit's early afternoon session focused on project research, development, and financing and its speakers represented state government, academia, and industry.

Alaska Department of Commerce, Community, and Economic Development (DCCED) Commissioner Susan Bell discussed the role of Alaska's abundant and diverse natural resources in the state's past, present, and future. In fulfilling its mission to promote a healthy economy and strong communities, DCCED's activities include fostering economic development, which requires a solid foundation of transportation, affordable energy, workforce development, and communications. Economic development tactics of marketing, finance, market resource, economic analysis, technical assistance and training, and policy input help increase opportunities for Alaska's natural resource and extraction industries (mining, timber, and fisheries). DCCED works with state and federal agencies and industry to conduct economic analysis and research, leads interagency coordination, and contributes to policy development in support of a healthy and attractive investment climate. Bell's remarks focused on three of DCCED's 13 agencies: the Division of Economic Development (DED), the Alaska Industrial Development and Export Authority (AIDEA), and the Alaska Railroad Corporation (ARRC).

DED works directly with the Alaska Minerals Commission, the Alaska Miners Association, and the Council of Alaska Producers to protect, promote, and advance the industry in Alaska, and collaborates with other state agencies and universities on mining issues. For example, with support from the Governor's Office, DED contracted the University of Alaska Fairbanks' Mineral Industry Research Laboratory (MIRL) to conduct primary research on developing rare-earth-element processing. DED also developed the State of Alaska Minerals and Mining Portal, a digital information collection delivered via thumb drive, and distributes hundreds of them annually at investor venues in Canada, New York, and elsewhere. DED participates on the inter-agency Large Mine Permitting Team (LMPT) and coordinates multi-agency state review of the obstacles to resource development in Alaska, such as the cost of energy, the need for additional transportation infrastructure, the need for project financing, and the impact of the Endangered Species Act.

AIDEA is the state's commercial development authority with loan interest participation and an expanding ability to invest directly in development projects. In his remarks at the summit, AIDEA Deputy Director Mark Davis stated that proposed projects must be endorsed by the local government, economically favorable to the state and the general public, and able to produce revenue that repays AIDEA's investment. All proposed AIDEA-financed projects must be approved by AIDEA's Board of Directors. The authority doesn't compete against the private sector, does not provide grants, and is not exclusive to large projects, Davis said.

Mining-related AIDEA projects include the Skagway Ore Terminal in Southeast Alaska and the DeLong Mountain Transportation System (DMTS) in Northwest Alaska. In 2011, the Alaska Legislature granted authority to AIDEA to issue bonds for an expansion of the Skagway terminal. AIDEA is currently working to develop the project and execute agreements with the terminal's users. AIDEA is also reviewing potential financing for transportation corridors in the Ambler mining district and considering the feasibility of expanding the DMTS to access the Lik zinc deposit. A new AIDEA fund has been established-the Sustainable Energy Transmission and Supply Development Program (SETS) - that provides the authority and tools to finance or facilitate financing for critical energy infrastructure projects. 
Another DCCED entity, the Alaska Railroad Corporation, moves goods and materials to and from tidewater. Its equipment and infrastructure is well suited for the dense, heavy, relatively low valueto-weight materials produced by mining, according to DCCED Commissioner Bell. In 2011, the railroad moved 2 million short tons of coal and more than 300,000 tons of mining materials such as grinding balls, cement and lime. With each train used to transport coal and gravel, hauling the equivalent of about 400 truckloads, significant transportation cost savings are realized, Bell said. The Alaska Railroad also transports oversized equipment to mining project sites or delivers the heavy equipment to locations where they are picked up by commercial trucking operations. Future development projects may take advantage of the extension of rail into Alaska's interior, over the Tanana River, and access to deep-water ports such as Port MacKenzie, she said. Both railway expansions are currently under construction.

In his remarks, University of Alaska Fairbanks Vice Chancellor for Research Mark Myers stated that UAF's research expertise spans the mining development cycle-from exploration to mine closure and reclamation. UAF is one of the few academic institutions in the United States that offers studies in both mining engineering and mineral processing. UAF is investing in new approaches to mineral exploration, such as hyperspectral mapping. UAF also collaborates with state agencies on geologic mapping, mineral processing studies, land selections, and other research efforts.

The MIRL includes labs devoted to coal, mineral processing, hydrometallurgy, electrochemistry, and mineral analysis. Lab capabilities include research and development related to mineral processing, mine ventilation, rock and soil stability, mine design, GIS software development, and mine economics. The university's Advanced Instrumentation Laboratory (AIL) offers researchers, as well as local, state, federal, and private agencies the benefits of cutting-edge analytical equipment such as spectrometers, microprobes, and other tools to assess elemental properties in rocks and minerals.

Ucore Rare Metals Chief Operating Officer Ken Collison gave a presentation on the Bokan-Dotson Ridge mineral project, located on Prince of Wales Island near Ketchikan. He emphasized the difference between light and heavy rare-earth oxides and their related economics. Bokan studies have shown that the ore body contains 40 percent heavy rare-earth oxides, which are critical to the development of clean energy applications such as hybrid vehicles and to national defense. At the time of his presentation, Collison said that heavy rare-earth oxides had a higher worth than light rare-earth oxides, due in part to their limited availability.

Ucore is considering a potential mine operations plan that would include establishment of a local camp, mill output of 1,500 tonnes per day (tpd), and trackless underground equipment. Ucore plans to hire locally and has determined a need for 190 on-site employees. Collison stated that this mine plan would have a small footprint: at closure, no tailings would be stored on the surface; instead, they would be put back underground as paste backfill. The mine would use x-ray sorters, and processing would incorporate a newly-developed solid phase extraction (SPE) process, which uses SPE columns to separate individual rare-earth elements from one another. This setup is small and quick with low capital and operating costs, he said. The company's current analysis predicts an 11 -year mine life with permitting to begin in 2013. However, the ore body is open at depth and on strike, and there are a number of other prospects on site. The project, in general, offers robust economics and a small footprint, utilizes new technology for the production of rare-earth oxides, and offers a great opportunity for the state, Collison said. 
Investing in Alaskans

http://www.dggs.alaska.gov/webpubs/dggs/mp/oversized/mp151_Mark Davis.pdf

Mark Davis, Deputy Director for Infrastructure Development, Alaska Industrial Development and Export Authority (AIDEA)

Mineral and Mining Research at UAF

http://www.dggs.alaska.gov/webpubs/dggs/mp/oversized/mp151 Mark Myers.pdf

Mark Myers, University of Alaska Fairbanks (UAF) Vice Chancellor for Research

Bokan Mountain Heavy Rare Earths

http://www.dggs.alaska.gov/webpubs/dggs/mp/oversized/mp151_Ken_Collison.pdf

Ken Collison, Chief Operating Officer, Ucore Rare Metals

\section{REGULATORY, STAKEHOLDER ISSUES, AND CLOSING REMARKS}

The final group of speakers during the minerals summit's late afternoon session focused on regulatory and community issues for mineral development in Alaska.

Donlin Gold Community Development and Sustainability Manager Mary Sattler provided an overview of the Dolin Gold project, a proposed large gold mine that recently entered the statefederal permitting process. Power needs for this mine in the Kuskokwim River region are equivalent to the current amount of power consumed in the entire Fairbanks area and would be met by constructing a natural gas pipeline to Cook Inlet. The company also plans two ports on the Kuskokwim River, a 30-mile road, a 600-man camp, sixty-nine 400-ton haul trucks, and a 5,000-foot runway. During construction, the project would have an annual estimated payroll of $\$ 375$ million; while operating, the mine's annual payroll is projected at $\$ 97$ million. The mine would provide an estimated 3,000 construction jobs and 600 to 1,400 permanent jobs during mine operation. Calista Corporation, the Bethel-based regional Native corporation that owns the subsurface at the deposit, would share 7(i) and 7(j) revenue with regional and village corporations statewide.

Located in a region with dozens of small Yupik Eskimo villages, Donlin focuses on providing local hire opportunities, Sattler said. At the time of her presentation, 90 percent of Donlin employees and 90 percent of Donlin supervisors were Calista shareholders or descendants of shareholders. Sattler stated that Donlin encourages local kids to graduate from high school and continue their education, highlighting opportunities available through the Alaska Native Science and Engineering Program (ANSEP), vocational and technical training, and scholarships and internships. These training opportunities can prepare students for the thousands of potential jobs at the mine.

Donlin's outreach efforts have focused on face-to-face communication, translation of company presentations into Yupik, company involvement in local activities such as science fairs, and the distribution of a local newsletter. Donlin also facilitates tours of the Fort Knox open-pit gold mine near Fairbanks, so that community residents can observe an existing open-pit gold mine operation in Interior Alaska.

Donlin emphasizes safety in its communications with its employees and the region's communities. Educating the local work force about safety helps spread the messages to their home communities. 
The company distributes safety equipment—such as life jackets—during visits to local subsistence fishing areas, Sattler said.

DNR Office of Project Management \& Permitting (OPMP) Director Tom Crafford presented an overview of the LMPT and a description of Alaska's operating mines, projects currently in permitting, and those in pre-permitting. There is no single, overarching permit that a company needs to obtain, Crafford said. Rather, mine permitting requires coordination of state and federal agencies and, potentially, local government permits and authorizations that vary for each project. The state agency members of the LMPT are led by an OPMP project coordinator who serves as the single point of contact for agencies, permit applicants, and stakeholders involved in a project. The project coordinator strives for parallel, simultaneous action and documentation that promote permitting efficiency and consistent decision making. The LMPT process is used only if an applicant has signed a Memorandum of Understanding with OPMP to fund Alaska state interagency participation.

The LMPT meets on a weekly basis and reviews the status of all major projects. The LMPT and the project coordinator remain engaged throughout the lifespan of a project, from baseline data collection, permitting, and operations to closure, reclamation, and post-closure monitoring. Crafford indicated that the calculation and maintenance of appropriate financial assurances for closure and reclamation are important components of the permitting process. The LMPT staff has significant expertise in project permitting, but will contract for additional expertise as needed.

In his remarks, Tower Hill Mines Inc.-Livengood Alaska General Manager Karl Hanneman discussed what works well with Alaska's large-mine permitting process. Hanneman focused on four strengths: early collaboration, decision making based on science, the application of appropriate expertise, and flexibility to respond to dynamic federal regulatory requirements. Red Dog, Greens Creek, Pogo, and Kensington mines, all permitted since 1989, have demonstrated that they can protect downstream fisheries including cleaning up naturally-polluted areas and protecting wetlands through the life of the mine, he said. Despite dynamic federal conditions, state agencies have done well at applying good science and knowledge on a consistent basis, he said.

Greater Fairbanks Chamber of Commerce Chairperson Lorna Shaw discussed the value of companies developing a "good will bank" in the communities where they do business, using Fairbanks as a case in point. Fairbanks serves as a hub for Interior mining projects. Up to 1,200 people living in the Fairbanks area are employed in mining, with an average mining wage of $\$ 100,000$. By utilizing not only local talent, but local goods and services, a company can further contribute to the local economy and provide additional, indirect jobs, she said. Engaging with a community is a two-way street. Project proponents and operators can be good neighbors by providing information at every opportunity, explaining who they are, where they are from, what they are doing, and what is happening if something goes wrong. In this way, the project can been seen and felt as part of the community. The community may be more vibrant because of this communication, and will be better able to respond to possible negative outside pressure because they are supportive and engaged in the project.

In closing remarks for the summit, Alaska Lieutenant Governor Mead Treadwell discussed the need for diversification in Alaska's economy. He argued that the aerospace industry in Alaska would benefit from an in-state supply of strategic and critical minerals. Treadwell applauded the work that has been accomplished on Governor Sean Parnell's five-part strategic minerals strategy since it was introduced at the 2011 minerals summit. He also recognized the Alaska legislators who attended the 
summit and thanked them for approving nearly $\$ 3$ million in budget requests to support the state's ongoing strategic and critical minerals assessment and funding for the Roads to Resources initiative.

Treadwell also noted that while the state often disagrees with the federal government on resource development issues, federal and state cooperation remains critical. If Alaska has the opportunity to counterbalance China as a supplier of rare earths, it will contribute to U.S. security and create new competition in the global supply for these limited resources.

Mary Sattler's Presentation on Donlin Gold

http://www.dggs.alaska.gov/webpubs/dggs/mp/oversized/mp151_Mary Sattler.pdf

Mary Sattler, Manager of Community Development and Sustainability, Donlin Gold

Large Mine Permitting in Alaska

http://www.dggs.alaska.gov/webpubs/dggs/mp/oversized/mp151 Tom Crafford.pdf

Director Tom Crafford, Alaska Department of Natural Resources, Office of Project Management and Permitting 
APPENDIX

I. AGENDA

\section{Alaska Strategic \& Critical Minerals Summit}

November 30, 2012 * Fairbanks Princess Riverside Lodge * Fairbanks, Alaska

\section{AGENDA}

WELCOME

8:30 a.m.

Welcome: Mayor Luke Hopkins, Fairbanks North Star Borough Mayor Jerry Cleworth, City of Fairbanks

Agenda Overview

Update on State of Alaska Strategic Minerals Initiative: Dan Sullivan,

Commissioner, Alaska Department of Natural Resources (DNR)

\section{MORNING ADDRESS}

9 a.m.

The Honorable U.S. Senator Lisa Murkowski, Ranking Member, U.S. Senate Committee on Energy and Natural Resources (video address)

PRESENTATIONS: Investigating Alaska's Strategic Mineral Potential

9:15 a.m. Bob Swenson, State Geologist and Director of the Division of Geological \& Geophysical Surveys

Larry Meinert, Mineral Resources Program Director, U.S. Geological Survey (video address)

Curtis Freeman, President, Avalon Development Corporation

10:00 a.m. Coffee/Networking Break

PRESENTATIONS: Access to Alaska's Lands and Resources

10:10 a.m.

The Honorable Alaska Senator John Coghill, Alaska Senate Majority Leader

Ed Fogels, Deputy Commissioner, Alaska Department of Natural Resources

Ethan Schutt, Senior Vice President, Land \& Energy Development, CIRI

Matt Ganley, Vice President, Resources \& External Affairs, Bering Straits

Regional Corporation

Lance Miller, Vice President, Natural Resources, NANA Regional Corporation Joint session Q\&A

LUNCH and KEYNOTE ADDRESS

11:30 a.m.-12 p.m. Lunch

12 p.m.

Michael Silver, President and Chairman of the Board, American Elements

PRESENTATIONS: Strategic Minerals - National Policy and Global Security 
12:50 p.m. $\quad$ Dan McGroarty, President, American Resources Policy Network

Hiroyuki Katayama, Assistant General Manager, Japan Oil, Gas and Metals

Corporation (Vancouver Office)

Q\&A

1:45 p.m.

Coffee/Networking Break

PRESENTATIONS: Project Research, Development and Financing

2 p.m.

Susan Bell, Commissioner, Department of Commerce, Economic Development \& Community Affairs

Mark Myers, Vice Chancellor for Research, University of Alaska Fairbanks

Ken Collison, Chief Operating Officer, Ucore Rare Metals

Mark Davis, Deputy Director, Infrastructure Development, Alaska Industrial

Development and Export Authority

Q\&A

3:15 p.m.

Coffee/Networking Break

PRESENTATIONS: Regulatory and Stakeholder Issues

3:30 p.m.

Tom Crafford, Director, DNR Office of Project Management and Permitting

Karl Hanneman, Alaska General Manager, Livengood Gold Project, Tower Hill Mines Inc.

Mary Sattler, Manager, Community Development \& Sustainability, Donlin Gold

Lorna Shaw, Chairwoman, Greater Fairbanks Chamber of Commerce

4:30 p.m. Q\&A

CLOSING REMARKS

4:45 p.m.-5 p.m. The Honorable Lieutenant Governor Mead Treadwell

RECEPTION

6 p.m. -8 p.m.

Reception and Investor Networking at the Museum of the North

Hosted by the University of Alaska Fairbanks 
Alaska Department of Commerce, Community, and Economic Development (DCCED)

Alaska Department of Natural Resources (DNR)

Alaska Division of Economic Development (DED)

Alaska Division of Geological \& Geophysical Surveys (DGGS)

Alaska Industrial Development and Export Authority (AIDEA)

Alaska Native Claims Settlement Act (ANCSA)

Alaska Native Science and Engineering Program (ANSEP)

Alaska Railroad Corporation (ARRC)

American Resources Policy Network (ARPN)

Bering Straits Native Corporation (BSNC)

Cook Inlet Region, Incorporated (CIRI)

Japan Oil, Gas and Metals Corporation (JOGMEC)

Large Mine Permitting Team (LMPT)

Mineral Industry Research Laboratory (MIRL)

Ministry of Economy, Trade and Industry (METI)

National Petroleum Reserve Alaska (NPRA)

Office of Project Management \& Permitting (OPMP)

Prospectors and Developers Association of Canada (PDAC)

University of Alaska Fairbanks (UAF)

U.S. Geological Survey (USGS)

World Trade Organization (WTO) 